\title{
Mycosis Fungoides and Sezary Syndrome Primary Tumor-Skin TNM Finding v7
}

National Cancer Institute

\section{Source}

National Cancer Institute. Mycosis Fungoides and Sezary Syndrome Primary Tumor-Skin

TNM Finding v7. NCI Thesaurus. Code C88230.

A finding about one or more characteristics of mycosis fungoides and Sezary syndrome, following the rules of the TNM AJCC V7 classification system as they pertain to staging of the primary tumor (skin). 